Leounal of I JOURNAL OF LEGAL RESERCH

Volume 3, Issue 4 (2021), pp 511-538

Research

P-ISSN: 2715-7172 E-ISSN: 2715-7164

http://journal.uinjkt.ac.id/index.php/ilr

\title{
Pembaharuan Dalam Sistem Pembagian Waris Secara Proporsional ${ }^{*}$
}

\author{
Faiqah Nur Azizah ${ }^{1}$ \\ Universitas Islam Negeri Syarif Hidayatullah Jakarta \\ $\underline{10.15408 / j \mid r . v 3 i 3.20935}$
}

\begin{abstract}
The purpose of this research is to identify and analyze the concept and legitimacy of reform in the Islamic inheritance distribution system in relation to men and women. The portion determined in QS al-Nisấ verses 11-12 concerning the division of inheritance and the party entitled to receive the inheritance is regulated in detail, with implications for the ijtihad of scholars who position the verse as a qat'iyu al-Wurud verse (certainly the origin of the syar'i) and qat'iyu al-Dalâlah verse (definite designation on a certain meaning). The presence of the concept of renewal in the proportional inheritance distribution system answers the ulama's previous rigidity in conducting ijtihad. This study employs a qualitative research method in conjunction with a literature review. According to the study's findings, reforms in the Islamic inheritance distribution system that are proportional to men and women can be implemented. Given the very dynamic nature of law and Islam as a religion of mercy for the universe, it responds to this dynamic through the concept of ijtihad for religious leaders, judges, and the government in order to answer the problems faced by society based on the context of the times, conditions, time, and place.
\end{abstract}

Keywords: Renewal; Inheritance; Proportional; Religious Court Decision

* Received: 20 May 2021, Revision: 06 June 2021, Publish: 15 July 2021.

${ }^{1}$ Faiqah Nur Azizah adalah Alumni Fakultas Syariah dan Hukum UIN Syarif Hidayatullah Jakarta. Jl. Ir. H Juanda, No.95, Ciputat, 15412. Email: faiqahnurazizah@gmail.com 


\section{A. PENDAHULUAN}

Persoalan pembagian waris menjadi salah satu pembahasan fikih yang sangat penting, ${ }^{2}$ karena hukum waris menjadi bagian dari hukum kekeluargaan yang sangat erat kaitannya dengan ruang lingkup kehidupan manusia, sebab setiap manusia pasti akan mengalami peristiwa hukum yang dinamakan kematian. ${ }^{3}$ Penyelesaian hak serta kewajiban dari akibat peristiwa kematian seseorang tersebut diatur di dalam cabang ilmu hukum Islam yang disebut dengan 'Ilmu Farâid. Di dalamnya memuat aturan secara terperinci dan sistematis mengenai hukum kewarisan, tidak hanya mengatur mengenai siapa pewaris dan yang berhak menerima warisan, namun juga mengatur apa yang diwariskan serta bagian yang berhak diterima secara mendetail. ${ }^{4}$

Ahli hukum seperti 'Abdu al-Wahhab Khallaf mengakui model yang terkandung dalam hukum waris canggih dan lengkap. Hal ini terjadi karena tidak ada aspek hukum secara teknis dalam hukum Islam yang memiliki keistimewaan karena tertulis ke dalam teks secara rinci, sistematis, dan realistis sehingga menutup kemungkinan adanya multi interpretasi. ${ }^{5}$ Pemaparan di dalam al-Qurân yang mengatur secara rinci dan detail mengenai ayat waris berimplikasi terhadap keyakinan ulama klasik, dimana mereka beranggapan bahwa hukum kewarisan tidak dapat diubah, sehingga mereka menolak adanya ide pembaharuan.

Berkaitan dengan kerincian yang terkandung dalam ayat waris tersebut, sebenarnya urgensi dari hadirnya hukum waris Islam adalah bertujuan untuk memberikan nilai-nilai keadilan dan kehormatan kepada umat Islam, khususnya dalam rangka menaikkan kedudukan serta derajat perempuan. Dikarenakan kondisi awal sebelum kedatangan Islam, kaum perempuan dianggap lemah dan tidak punya peran penting untuk kemajuan suku dan klan. Hal ini berimplikasi pada hak perempuan untuk tidak mendapatkan harta warisan, mereka bahkan menjadi objek yang dapat diwariskan secara turunmenurun. Sehingga kondisi bangsa Arab saat Islam datang berada pada budaya patriarki dan ditopang dengan sistem kekerabatan patrilineal yang kuat. Pada

${ }^{2}$ Hasniah Hasan, Hukum Warisan Dalam Islam, (Surabaya: Bina Ilmu, 1994), h. 1.

${ }^{3}$ Eman Suparman, Hukum Waris Indonesia: Dalam Perspektif Islam, Adat, dan BW, (Bandung: Refiks Aditama, 2005), h. 1.

4 Afif Muamar, "Rekonstruksi Hukum Islam (Telah Pemikiran Muhammad Syahrur)", Jurnal Mahkamah Kajian Hukum Islam, 2, 2, (Desember 2017), h. 206.

${ }^{5}$ Sunardi Panjaitan, Skripsi Teori Batas Hukum Islam: Studi Terhadap Pemikiran Muhammad Syahrur Dalam Waris, (Skripsi S-1 Fakultas Syariah dan Hukum, Universitas Islam Negeri Syarif Hidayatullah Jakarta, 2008), h. 2. 
gilirannya sistem ini membentuk suatu sistem budaya yang memprioritaskan laki-laki di atas segalanya, sedangkan perempuan dipandang sebagai objek kehidupan. ${ }^{6}$ Dengan demikian, kehadiran hukum waris Islam yang memberikan hak kepada perempuan dalam pembagian warisan memberikan keterangan bahwa secara sadar Islam hendak mengangkat hak dan derajat perempuan. ${ }^{7}$

Ternyata persoalan keadilan tidak selesai pada saat hukum Islam hadir dengan memberikan hak warisan kepada perempuan. Problematika ini terus berlanjut hingga tataran pemikiran para fuqaha', mufassir, dan pemikir Islam, hal ini tentu dipengaruhi oleh kondisi sosial yang sangat patriarki sehingga mempengaruhi ijtihadnya. Padahal struktur masyarakat di dunia bukan hanya patrilinear, tapi juga berstuktur matrilinear dan bahkan bilateral. ${ }^{8}$

Dalam menghadapi perbedaan struktur masyarakat tersebut, maka penasiran dari makna yang terkandung dalam nas al-Quran tersebut harus dapat menyesuaikan perubahan struktur sosial yang dihadapi oleh umat manusia. Sehingga semangat al-Quran dapat bersifat universal, rasonal dan sesuai dengan kebutuhan. Disinilah peran para ahli (fuqaha dan ulama) dibutuhkan agar terus memaksimalkan power of reasoningnya untuk mencairkan dan mengalirkannya ke segala ruang dan waktu. Tidak ada hal lain selain untuk menujukkan bahwa watak Islam sebagai hukum berjalan dengan dinamis dan dapat memberikan solusi terhadap masalah yang terjadi di setiap perubahan sosial tanpa sedikitpun mengabaikan prinsip-prinsip yang terkandung di dalamnya, yakni tegaknya kemaslahatan, keadilan dan kesetaraan manusia. ${ }^{9}$

Sejalan dengan hal itu Muhammad Syahrûr tokoh pembaharu asal MesirSyiria beranggapan bahwa hukum kewarisan Islam yang saat ini dikaji dan dikembangkan oleh pemikir Islam, masih menyisakan problematika yang harus diselesaikan dengan upaya pembaharuan. Menurut Muhammad Syahrûr, Hukum Islam tidak harus diberlakukan secara literal teks, hal ini agar Islam tidak kehilangan karakter keluwesan dan fleksiblelitasnya. Pemikiran

${ }^{6}$ Sugiri Permana, "Kesetaraan Gender dalam Ijtihad Hukum Waris Islam di Indonesia", Jurnal Asy-Syari'ah, 20, 2, (Desember, 2012), h. 120.

${ }^{7}$ Ibid.

${ }^{8}$ Atho Mudzhar dan Khairuddin Nasution, ed.al, eds., Hukum Keluarga di Dunia Islam Modern, (Jakarta Selatan: Ciputat Press, 2003), h. 204.

${ }^{9}$ Hilal Malarangan, "Pembaharuan Hukum Islam Dalam Hukum Keluarga di Indonesia", Jurnal Hunafa, 5, 1, (April, 2008), h. 38.

Journal of Legal Research. Volume 3, Nomor 4 (2021). ISSN: 2715-7172. E-ISSN: 2715-7164 - 513 
Muhammad Syahrûr tersebut dituangkan dalam sebuah teori yang dikenal dengan Teori Limit (Teori Batas).

Hal ini senada dengan pemikiran Munawwir Sadzali yang mampu mendobrak tatanan baru pola pemikiran hukum Islam ketika dihadapkan antara konteks dan teks Islam. Secara genial Munawir Sadzali mampu mengintegrasikan gagasan-gagasan dalam berbagai tradisi yang berbeda dengan merumuskan kerangka teoritisnya yang dikenal dengan teori Reaktualisasi Ajaran Islam. Pemikirannya sangat relevan dengan kondisi sosial Indonesia khususnya dalam bidang kewarisan Islam yang menganut sistem kekerabatan bilateral, sehingga penerapan hukum Islam sangat dinamis dan dapat disesuaikan dengan kondisi dan zaman dimana hukum Islam itu diaplikasikan.

Teori dari pemikiran Muhammad Syahrûr dan Munawir Sadzali kemudian digunakan oleh Majelis Hakim Pengadilan Agama sebagai Pertimbangan Hukum dalam memutuskan perkara waris dengan pembagian proporsional sebagaimana tertuang dalam amar Putusan Nomor No.92/Pdt.G/2009/PA.Mdn. Putusan ini menunjukkan bahwa hakim dalam memutuskan putusannya harus mengedepankan rasa keadilan bagi masyarakat dengan menelaah terlebih dahulu 'illat hukum yang terkandung dalam suatu teks nas al-Qurân.

Berangkat dari persoalan di atas, penulis beranggapan bahwa sistem pembagian waris 2:1 yang biasa berlaku, faktanya belum dapat menjawab problematika keadilan waris bagi perempuan, karena perubahan dan perbedaan yang terjadi dalam konstruksi sosial kehidupan masyarakat. Untuk itu menurut penulis, mengetahui pembaharuan pembagian waris secara proporsional sangat penting pada zaman sekarang ini, mengingat banyak perubahan-perubahan yang terjadi pada peran perempuan karena keterlibatannya dalam segala aktifitas yang dahulu hanya dikerjakan oleh lakilaki, misalnya keterlibatan istri dalam mencari nafkah.

\section{B. METODE PENELITIAN}

Metode yang digunakan dalam penelitian ini adalah kajian kepustakaan, yaitu studi yang objek penelitiannya berupa karya-karya kepustakaan, baik berupa jurnal ilmiah, buku buku-buku para ahli yang memberikan pendapatpendapat, pengalaman, ide-ide, teori-teori tentang permasalahan penelitian, maupun artikel dalam media massa. Kepustakaan tersebut akan digunakan untuk menjawab permasalahan penelitian yang diajukan oleh penulis yang dalam hal ini adalah: Pertama, Bagaimana konsep pembaharuan dalam sistem 
pembagian warisan secara proporsional antara laki-laki dan perempuan? Kedua, Bagaimana legitimasi hukum Islam di Indonesia terhadap pembaharuan sistem pembagian warisan secara proporsional antara laki-laki dan perempuan? Adapun sifat dari studi yang dilakukan adalah deskriptif analisis yaitu memberikan edukasi dan pemahaman kepada pembaca, serta jenis data yang digunakan dalam penelitian ini adalah data primer yang ditulis langsung oleh tokoh bersangkutan yang menuliskan teori atau sistematika pembagian waris secara proporsional

\section{HASIL TEMUAN DAN PEMBAHASAN}

\section{Legitimasi Hukum Islam di Indonesia Terhadap Pembaharuan Sistem Pembagian Warisan Secara Proporsional Antara Laki-Laki Dan Perempuan}

Legitimasi hukum pembagian hak waris menurut Hukum Waris Islam di Indonesia, yakni diatur di dalam Sumber Hukum Formiil berupa Kompilasi Hukum Islam (Intruksi Presiden No. 1 Tahun 1991) Pasal 176 yang berbunyi:

"Anak perempuan bila hanya seorang ia mendapat separoh bagian, bila dua orang atau lebih mereka bersama-sama mendapat dua pertiga bagian, dan apabila anak perempuan bersama-sama dengan anak laki-laki, maka bagian anak laki-laki adalah dua berbanding satu dengan anakperempuan."

Sebagaimana yang termaktub dalam Kompilasi Hukum Islam Pasal 176, menurut penulis bunyi pasal yang dimasukkan kedalam pasal 176 disadur dari makna secara tekstual yang terdapat di dalam ayat 11 Q.S al-Nisâ' yang berbunyi:

“Allah mensyari'atkan bagimu tentang (pembagian pusaka untuk) anakanakmu. Yaitu: bahagian seorang anak lelaki sama dengan bagian dua orang anak perempuan; dan jika anak itu semuanya perempuan lebih dari dua, maka bagi mereka dua pertiga dari harta yang ditinggalkan; jika anak perempuan itu seorang saja, maka ia memperoleh separo harta..."

Pembagian hak waris berdasarkan Kompilasi Hukum Islam Pasal 176 menunjukkan pembagian waris berdasarkan prinsip pembagian 2:1 sebagaimana yang terdapat dalam Q.S. al-Nisâ' ayat 11. Namun di dalam sumber hukum formiil lainnya yakni Putusan Pengadilan Agama Medan Nomor 92/Pdt.G/2009/PA.Mdn yang di dalam putusan akhir, hakim memberikan hak bagian waris kepada masing-masing ahli waris berdasarkan prinsip pembagian 1:1 atau pembagian secara proporsional. Tentu putusan Pengadilan Agama Medan ini dapat menjadi yurisprudensi atau legitimasi 
hukum yang dapat digunakan oleh hakim kemudian hari, sebagai rujukan pertimbangan hukumnya jika terdapat kesamaan peristiwa.

Dalam pembagian hak waris berdasarkan putusan Pengadilan Agama Medan Nomor 92/Pdt.G/2009/PA.Mdn, menurut penulis hakim tersebut berani keluar dari aturan hukum yang biasa berlaku dan tidak terikat pada budaya yang berlaku umum di lingkungannya. Sebagaimana yang diketahui bahwa budaya yang dianut oleh masyarakat Medan menempatkan laki-laki pada posisi utama dengan meletakkan marga dan keturunan berdasarkan garis keturunan bapak (patrilinear).

Tentu ada alasan tertentu yang menjadi pertimbangan hakim dalam memutuskan perkara waris ini, sebagaimana di dalam pertimbangan hukum disebutkan:

"Majelis hakim berijtihad terhadap pembagian harta warisan sebagaimana yang terjadi di dalam kasus di atas, baik dalam ayat al-Qurân maupun Kompilasi Hukum Islam bukanlah harga mati dari sebuah ketentuan yang sama sekali tidak dapat dirubah lagi, terutama ketika permasalahannya terkait dengan rasa keadilan para ahli waris, dan rasa keadilan itu sendiri merupakan 'illat hukum (penyebab yang dapat mengakibatkan terjadinya perubahan hukum)."

Hal ini tidak berarti bahwa ijtihâd yang dilakukan hakim Pengadilan

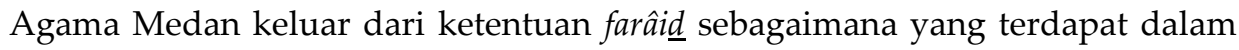
Q.S al-Nisâ' ayat:11, namun penulis menilai bahwa hakim Pengadilan Agama Medan memiliki maksud mengutamakan prinsip keadilan yang menjadi 'illat hukum dalam penetapan hukum waris Islam. Seperti yang ditegaskan dalam pertimbangan hukumnya:

"Majelis hakim tetap menentukan asas pembagian harta peninggalan antara laki-laki dan perempuan adalah dua berbanding satu, akan tetapi apabila fakta kejadian menghendaki, maka porsi dua bagian laki-laki dan porsi satu bagian perempuan sewaktu-waktu dapat berubah sesuai dengan perubahan 'illat hukum."

Selanjutnya dalam pertimbangan hukum disebutkan:

"Sehingga porsi dua untuk anak laki-laki adalah porsi maksimal yang dapat dikurangi, sedang porsi satu bagian anak perempuan adalah porsi minimal yang sewaktu-waktu apabila persyaratan menghendaki dapat meningkat sama dengan perolehan anak laki-laki."

Pertimbangan majelis hakim tersebut memiliki kolerasi dengan teori limit Muhammad Syahrûr yang menyatakan bahwa batas minimal porsi 
perempuan yakni satu bagian yang tidak boleh dikurangi dan bagian maksimal laki-laki yakni dua bagian yang tidak boleh ditambahkan. ${ }^{10}$ Walaupun teori limit Muhammad Syahrûr memiliki batasan-batasan tertentu dalam penerapannya, yakni berdasarkan batasan minimal dan batasan maksimal, namun dalam batasan ini para mujtahid memiliki kebebasan untuk menetapkan batasan hukum terhadap suatu persoalan berdasarkan batasan minimal ataupun batasan maksimal yang telah ditentukan, yang tidak diperbolehkan adalah menerapkan ketentuan di luar batasan-batasan yang telah ditetapkan Allah. ${ }^{11}$

Di dalam pertimbangan hakim dalam putusan Pengadilan Agama Medan No. 92/Pdt.G/2009/PA.Mdn, majelis hakim mengambil berbagai sumber hukum yang menjadi dasar pertimbangan hukumnya, diantaranya adalah:

Pertama; Bersumber dari al-Qurân Surat al-Nahl (16) ayat 97 berkaitan dengan asas persamaan, yang berbunyi: "Barangsiapa yang mengerjakan amal soleh laki-laki maupun perempuan dalam keadaan beriman, maka sesungguhnya kami akan memberikan kepadanya kehidupan yang baik." Dalam Q.S al-Nahl (16) ayat 97 tersebut memberikan suatu gambaran tentang persamaan antara laki-laki dan perempuan, perbedaannya terletak pada prestasi atau pengabdian, dalam hal ini menunjukkan pada pengabdian ahli waris terhadap pewaris semasa hidupnya. Majelis hakim juga berpendapat bahwa tidak mungkin kitab suci alQurân membuat suatu diskriminasi kategoris berdasarkan jenis kelamin dalam hal pembagian harta peninggalan seseorang kalau bukan didasari oleh pertimbangan tertentu, atau karena kondisi masyarakat sewaktu turunnya ayat, karena al-Qurân mengajarkan asas persamaan antara laki-laki dan perempuan, adapun yang membedakan antara lain ialah kualitas amal perbuatannya.

Pertimbangan hakim ini memiliki kolerasi dengan yang disampaikan oleh Munawir Sadzali bahwa perempuan pada masa jahiliyyah yang ketika itu tidak mendapatkan hak waris, dengan kedatangan Islam derajat perempuan mulai diangkat dan dianggap peran serta keberadaannya dengan memberikan hak waris kepada perempuan walaupun separuh dari hak waris laki-laki. Pengangkatan derajat perempuan ini sebenarnya yang dibawa dalam semangat

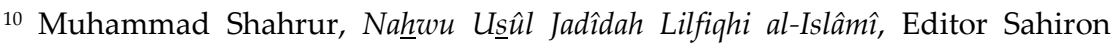
Syamsuddin, Metodologi Figh Islam Kontemporer, h. 342 dan lihat Imam Syaukani, Rekonstruksi Epistimologi Hukum Islam Indonesia (Jakarta: Raja Grafindo Persada, 2006), h. 145.

${ }^{11}$ Fuad Mustafid, "Pembaharuan Pemikiran Hukum Islam: Studi Tentang Teori Hudud Muhammad Syahrur", Jurnal Al-Madzahib, 5, 2, (Desember, 2017), h. 307. 
ajaran Islam untuk menyamakan derajat perempuan dengan laki-laki. Namun Islam melakukannya dengan cara bertahap sebagaimana dilakukan pengharaman terhadap khamr secara bertahap pula. Melihat peran perempuan dalam masyarakat modern ini sama dengan laki-laki, maka menjadi konsekuensi logis jika bagian hak waris untuk anak perempuan ditingkatkan sama dengan bagian hak waris untuk anak laki-laki. ${ }^{12}$

Kedua; Bersumber dari Doktrin. Pendapat hukum yang diambil dari


yang mengatakan: "Sebab lain mengapa bagian laki-laki lebih besar dari perempuan ialah karena laki-laki dibebani masalah hidup yang tidak mampu dijalankan oleh perempuan" untuk itu dalam pertimbangan hukumnya, majelis hakim berijtihad bahwa Mafhum mukhâlafah (pemahaman sebaliknya) dari pendapat tersebut adalah apabila perempuan dibebani masalah hidup, maka perempuan tersebut juga berhak memperoleh bagian yang lebih besar.

Pertimbangan hakim ini juga memiliki kolerasi dengan pendapat Muhammad Syahrûr yang cenderung menyoroti peran perempuan dalam hal keterlibatan mencari nafkah. Syahrûr menyatakan jika kondisi perempuan tidak ikut andil sama sekali dalam menafkahi keluarga, maka bagiannya adalah separuh dari bagian laki-laki sebagaimana yang terdapat dalam redaksi ayat 11 Q.S al-Nisâ'. Namun jika perempuan ikut andil dalam menafkahi keluarga, maka bagiannya bisa tidak ada perbedaan bagian antara laki-laki dan perempuan. ${ }^{13}$ Sehingga menurut penulis Muhammad Syahrûr memberikan suatu catatan penting bahwa porsi pembagian waris itu tergantung kepada kondisi dan peran perempuan dalam keterlibatannya untuk menafkahi keluarga yang seharusnya tanggung jawab tersebut dibebankan kepada lakilaki.

Ketiga; Bersumber dari kaidah uŝûl figh yang berbunyi:



Artinya: "tidak dapat diingkari terjadinya perubahan hukum karena perubahan waktu, tempat dan kondisi tertentu"

${ }_{12}$ Hasbullah Mursyid, "Menelusuri Faktor Sosial yang Mungkin Berpengaruh" dalam Muh. Wahyuni Nafis, Kontekstualisasi Ajaran Islam (70 $0^{\text {th }}$ Prof Munawir Syadzali), (Jakarta: Paramadina dan IPHI, 1995), h. 205.

${ }^{13}$ Abdul Aziz, "Pembagian Waris Berdasarkan Tingkat Kesejahteraan Ekonomi Ahli Waris dalam Tinjauan Maqashid Shariah", De Jure: Jurnal Hukum dan Syari'ah, 8, 1, (Juni, 2016), h. 52. 
dan juga salah satu kaidah us ul figh yang berbunyi:

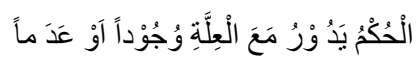

"Penerapan hukum itu (harus) memperhatikan ada atau tidaknya 'illat hukum"

Penulis menilai dari putusan Pengadilan Agama Medan No. 92/Pdt.G/2009/PA.Mdn ini memiliki perbedaan prinsip dengan Kompilasi Hukum Islam, yang mana Kompilasi Hukum Islam menggunakan prinsip pembagian 2:1 dan Putusan Hakim Pengadilan Agama Medan Nomor 92/Pdt.G/2009/PA.Mdn menggunakan prinsip pembagian 1:1. Perbedaan prinsip pembagian waris tersebut terjadi karena kondisi tertentu hukum itu diterapkan. Ketika memang kondisi penerapan hukum waris dalam keadaan normal dan tanpa ada perdebatan diantara ahli waris mengenai porsi pembagian harta warisan, maka hukum waris diterapkan sebagaimana mestinya berdasarkan prinsip 2:1 sesuai dengan Q.S al-Nisâ' ayat 11, dan Kompilasi Hukum Islam Pasal 176. Namun ketika kondisi penerapan hukum waris memiliki perdebatan diantara ahli waris mengenai porsi pembagian harta warisan karena kondisi tertentu, maka perlu pertimbangan dan kebijaksanaan dari para mujtahid, qâdi dan âmîr untuk mengkaji ulang 'illat hukum yang terdapat dalam hukum waris Islam berdasarkan prinsip keadilan secara proporsional yakni pembagian berdasarkan prinsip 1:1.

Sebagaimana yang termaktub di dalam ketentuan Pasal 5 ayat (1) UU No. 48 tahun 2009 Tentang Kekuasaan Kehakiman menyebutkan bahwa: "Hakim dan hakim konstitusi wajib menggali, mengikuti, dan memahami nilai-nilai hukum dan rasa keadilan yang ada dalam masyarakat" Juga berdasarkan Pasal 10 ayat (1) yang menyebutkan bahwa: "Pengadilan tidak boleh menolak untuk memeriksa, mengadili, dan memutuskan suatu perkara yang diajukan dengan dalih bahwa hukum tidak ada atau kurang jelas, melainkan wajib untuk memeriksa dan mengadilinya." Hal ini menunjukkan bahwa keadilan wajib ditegakkan walaupun tidak ada ketentuan normatif, dan hakim memiliki kewajiban untuk dapat menggali, mengikuti, memahami nilai-nilai hukum dan rasa keadilan yang ada dalam masyarakat.

Analisis penulis selanjutnya mengenai pembagian harta warisan dalam putusan Pengadilan Agama Medan No. 92/Pdt.G/2009/PA.Mdn bahwa majelis hakim menyatakan: "ketentuan dalam ayat al-Qurân tersebut (al-Nisầ' ayat 11), majelis hakim tidak pada tempatnya untuk melakukan uji materil apapun metodenya, karena persoalannya menyangkut keyakinan agama uang dianut, akan tetapi menafsirkan ayat tersebut sesuai dengan fakta kejadian perkara adalah tetap dalam wilayah direksi hakim." Kemudian disebutkan dalam pertimbangan selanjutnya 
"bahwa pembagian harta warisan sebagaimana tersebut baik dalam al-Qurân maupun Kompilasi Hukum Islam bukanlah sebuah harga mati yang sama sekali tidak dapat dirubah lagi, terutama ketika permasalahanya terkait dengan rasa keadilan itu sendiri merupakan salah satu 'illat hukum (penyebab yang dapat mengakibatkan terjadinya perubahan hukum)."

Dengan penjelasan berdasarkan pertimbangan hakim di atas, penulis menilai bahwa secara eksplisit majelis hakim telah berijtihad mengenai pembagian waris dalam surat al-Nisâ' ayat 11 merupakan kategori ayat zanny, karena hakim dapat melakukan ijtihad terhadap ayat tersebut. Jika hakim menganggap bahwa ayat ini merupakan kategori ayat yang qaț $i$, maka tidak seharusnya majelis hakim melakukan ijtihad terhadap ayat waris tersebut. Sebab selama nas itu qat́iyu al-Wurud (pasti asal muasalnya dari syar'i) dan bersifat qat'iyu al-Dalâlah (penunjukan pasti pada makna tertentu), maka sudah seharusnya tidak ada tempat untuk membahas dan berijtihad tentang makna dan ketetapan hukumnya. ${ }^{14}$

Formulasi dalam sistematika pembagian waris telah diatur secara jelas dan detail dalam ayat waris tersebut mengindikasikan sulit adanya kemungkinan multiinterpretasi. Sehingga biasanya penafsiran yang dihasilkan dari ayat waris ini cenderung bersifat tekstual. Oleh karena itu pertimbangan ini menurut penulis, majelis hakim seharusnya terlebih dahulu mengurai lebih dalam posisi ayat waris tersebut apakah masuk kedalam kategori ayat qat ${ }^{\prime} i$ atau kategori ayat zanny serta alasan penerapan putusan berdasarkan kategoris ayat tersebut. Dengan begitu uraian pertimbangan majelis hakim memiliki pijakan hukum yang jelas.

Dari uraian berdasarkan pertimbangan hukum majelis hakim dalam Putusan Medan No. 92/Pdt.G/2009/PA.Mdn, menurut penulis Surat al-Nisâ' ayat 11 ini menjadi prinsip utama waris yang kemudian melahirkan berbagai polemik perbedaan paradigma diantara para ulama, hakim dan mujtahid. Perbedaan paradigma tersebut justru menurut penulis perlu dirawat bahkan perlu ada upaya pengembangan teori hukum Islam yang sesuai dengan kebutuhan tempat dan zaman hukum waris diterapkan. Sebagaimana yang dikatakan oleh John Rawls: "Suatu teori, betapapun elegan dan efesien harus ditolak

${ }^{14}$ Mukhtar Yahya dan Fatchurrahman, Dasar-dasar Pembinaan Hukum Fiqh Islam, (Bandung: Al-Ma'arif, 1993), Cet. 3, h. 373. 
atau direvisi jika tidak benar. Begitupun dengan intitusi dan hukum tidak peduli betapapun efesien dan rapih, harus direformasi jika tidak mencerminkan keadilan". ${ }^{15}$

Dari pernyataan ini, John Rawls menghendaki adanya upaya untuk melakukan reformasi hukum, jika hukum itu tidak lagi mencerminkan keadilan. Begitupun dalam hukum waris yang secara tekstual mengatur pembagian harta waris secara rapih dan detail, perlu dilakukan upaya pengkajian ulang dan reformasi hukum yang memberikan rasa keadilan bagi masyarakat, sehingga penyimpangan dan dualisme dalam penerapan hukum waris dapat dihilangkan. Tentu perlu adanya formulasi yang tepat untuk melakukan pembaharuan dalam sistem pembagian waris, mengingat saat ini budaya patriarki masih sulit dihilangkan dari kehidupan masyarakat karena budaya tersebut secara tidak langsung diwariskan secara turun-menurun dari generasi ke generasi hingga menjadi sebuah doktrin yang hidup bersama masyarakat.

Dalam merumuskan formulasi yang tepat kedudukan antara laki-laki dan perempuan, sebenarnya secara sadar Islam mengajarkan dan memandang sama kedudukan antara perempuan dan laki-laki. Hal ini dapat dilihat pada kewajban dalam bidang mu'amalah, kewajiban menuntut ilmu, dan hal yang berkaitan dengan segala sesuatu tentang kemashlahatan, baik berkaitan dengan pemeliharaan jiwa, akal, maupun berkaitan dengan harta benda. ${ }^{16}$ Selain itu fakta menarik yang ditemukan oleh Dr. Ramizah Wan Muhammad berkaitan dengan penyebutan perempuan dan laki-laki di dalam al-Qurân, bahwa alQurân menyebutkan kata al-Nisâ' sebanyak 57 kali dan kata al-Rijâl sebanyak 57 kali. Hal ini menunjukkan pentingnya kesetaraan antara laki-laki dan perempuan dalam Islam dan kontribusi keduanya dalam perkembangan hukum Islam dan secara bersamaan juga ajaran Islam menunjukkan bahwa laki-laki dan perempuan adalah setara. ${ }^{17}$ Secara eksplisit konsep tersebut memiliki kolerasi yang sama dengan teori keadilan menurut Aristoteles yang mengutamakan keadilan sebagai perimbangan dan proporsi juga sebagaimana

${ }^{15}$ John Rawls, A Theory of Justice. Penerjemah Uzair Fuzan dan Heru Prasetyo, Teori Keadilan: Dasar-dasar Filsafat Politik untuk Mewujudkan Kesejahteraan Sosial dalam Negara, h. 3.

16 Huzaemah T. Yanggo, Hukum Keluarga Dalam Islam, (Jakarta: Yayasan Masyarakat Indonesia Baru, 2013), h. 7.

17 Razimah Wan Muhammad, "Woman and Shari'ah Court: A Study of Malaysia and Indonesia", International Journal of Cross-Cultural Studies, 1, 2, (Desember, 2015), h. 42.

Journal of Legal Research. Volume 3, Nomor 4 (2021). ISSN: 2715-7172. E-ISSN: 2715-7164 - 521 
teori keadilan menurut Thomas Aquinas yang mengartikan keadilan sebagai kesamaan secara proporsional.

Pemahaman mengenai konsep pembagian hukum waris secara proporsional tersebut seringkali terhalang oleh pemahaman mengenai formulasi hukum waris merupakan perintah Tuhan yang berasal dari al-Qurân dan hadis sehingga menjadi suatu ketetapan yang tetap dan bukan menjadi wilayah ijtihâd manusia. Namun hal mendasar yang tidak boleh terabaikan dalam memahami adanya konsep perumusan pembagian waris adalah kondisi ketika awal turun ayat waris yang tidak terlepas dari pengaruh budaya di mana Islam pertama kali berkembang di tanah Arab. Akibatnya aspek substantif dari kewarisan Islam dibangun atas dasar logika patriarki dengan menempatkan status ahli waris laki-laki lebih tinggi dibanding ahli waris perempuan. Hal ini menurut anggapan ilmuan hukum yang memicu benang patrilinealisme dalam masyarakat Arab bercampur dengan sistem kewarisan Islam. ${ }^{18}$

Senada dengan itu, dalam konteks struktur budaya masyarakat modern, perubahan paradigma mengenai kedudukan perempuan secara tidak langsung mempengaruhi ijtihâd ulama kontemporer dalam merumuskan ulang formulasi yang tepat dalam waris Islam. Hal ini sebagaimana tercermin pada Putusan Pengadilan Agama Medan No. 92/Pdt.G/2009/PA.Mdn.

Eksistensi Peradilan Agama dalam penerapan hukum Islam sebagaimana yang diputuskan dalam Putusan Pengadilan Agama Medan No. 92/Pdt.G/2009/PA.Mdn oleh majelis hakim semakin kukuh dengan kehadiran Undang-undang No. 50 Tahun 2009 Tentang Perubahan Kedua Undangundang No. 7 Tahun 1989 Tentang Peradilan Agama. Sebagaimana dalam Pasal 1 ayat (1) disebutkan bahwa "Peradilan Agama adalah peradilan bagi orang-orang yang beragama Islam" diperkuat dengan pasal 2 yang berbunyi "Peradilan Agama adalah salah satu pelaku kekuasaan kehakiman bagi rakyat pencari keadilan yang beragama Islam mengenai perkara tertentu sebagaimana dimaksud dalam. Undangundang ini." Pengertian perkara yang dimaksud dalam pasal 2 dijelaskan lebih lanjut di dalam pasal 49 yang berbunyi "Pengadilan Agama bertugas dan berwenang memeriksa, memutus, dan menyelesaikan perkara di tingkat pertama antara orang-orang yang beragama Islam di bidang: a) Perkawinan; $b$ ) waris; c) wasiat; d) hibah; e) wakaf; f) zakat; g) infaq; shadaqah dan; h) ekonomi syari'ah." Pasal ini menurut Moh. Muhibbin dan Abdul Wahid menegaskan bahwa

18 Ratno Lukito, Hukum Sakral dan Hukum Sekuler: Studi Tentang Konflik dan Resolusi dalam Sistem Hukum Indonesia, (Tangerang: Pustaka Alvebet, 2008), h. 465. 
kewarisan bagi umat Islam di seluruh Indonesia penyelesaiannya menjadi wewenang Pengadilan Agama. ${ }^{19}$ Hal ini menunjukkan bahwa Pengadilan Agama memiliki status dan kewenangan yang kuat sebagai hukum positif dalam penyelesaian sengketa waris, sekaligus memiliki kewenangan untuk memberikan putusan yang mengikat secara yuridis formil.

\section{Konsep Pembaharuan Sistem Pembagian Warisan Secara Proporsional Antara Laki-Laki Dan Perempuan}

Sesuatu yang menarik dari hukum waris bukan hanya karena kompleksitas peralihan harta dari pewaris kepada ahli waris atas harta yang ditinggalkan, namun yang lebih penting dan sering menjadi perdebatan intelektual adalah mengenai kedudukan wanita dan hak-haknya dalam perolehan harta warisan dalam konteks perkembangan peran wanita di era modern saat ini. Hal ini oleh sebagian pemikir kontemporer, seperti Muhammad Syahrûr dan Munawir Sadzali menganggap rumusan hukum waris Islam belum mencerminkan nilai keadilan, sehingga muncul berbagai gagasan dan pemikiran untuk mencoba melakukan pengkajian ulang terhadap akar-akar ketentuan waris beserta rumusan hukumnya. Dengan demikian pemikir kontemporer berasumsi bahwa terdapat kesenjangan di dalam hukum kewarisan Islam berkaitan dengan akar-akar ketentuan waris di dalam alQurân. Selain itu, terdapat kemungkinan bahwa hukum kewarisan Islam terbentuk oleh faktor ruang dan waktu, serta kepentingan sosial politik yang mempengaruhi rumusan hukum kewarisan Islam pada saat itu.

Menanggapi ide pembaharuan dalam konteks hukum waris Islam khususnya berkaitan dengan prinsip pembagian warisan 1:1 atau pembagian secara proporsional tersebut menurut Amin Suma merupakan suatu tindakan terlampau terburu-buru dan kurang argumentatif, dalam artian tidak memiliki pemikiran hukum Islam yang kuat dari sisi normatif-tekstualis apalagi dari sudut pandang dalil yang substantif-kontekstualis. ${ }^{20}$ Senada dengan hal tersebut, Imam al-Tabari menyebutkan bahwa ayat yang berkaitan dengan kewarisan Islam, khususnya sebagaimana terdapat dalam Q.S al-Nisâ' ayat 11 merupakan nas s sarih dan qați al-dalâlah, sehingga istinbat hukum pembagian

${ }^{19}$ Moh. Muhibbin dan Abdul Wahid, Hukum Kewarisan Islam: Sebagai Pembaharu Hukum Positif di Indonesia, (Jakarta: Sinar Grafika Bumi Aksara, 2011), h. 45.

${ }^{20}$ Muhammad Amin Suma, Keadian Hukum Waris Islam: Dalam Pendekatan Teks dan Konteks, (Jakarta: PT. Grafindo Persada, 2013), Cet. 1, h. 73.

Journal of Legal Research. Volume 3, Nomor 4 (2021). ISSN: 2715-7172. E-ISSN: 2715-7164 - 523 
warisan antara laki-laki dan perempuan sesuai secara tekstual dengan Q.S alNisâ' ayat 11 tersebut, yakni dengan prinsip pembagian 2:1.21

Demikian juga yang disampaikan oleh Zamakhsyarî al-Khawârizmî bahwa bagain-bagian waris tersebut telah ditentukan secara pasti sebagaimana bunyi redaksi ayat dalam QS. al-Nisâ': 7 ذَصِيدًا مَفْرُوضدًا. Redaksi tersebut memiliki makna "dinasabkan dengan pertimbangan khusus" maksudnya bahwa sesungguhnya Allah telah memberikan bagian yang telah ditentukan secara pasti dan wajib serta mengharuskan umat muslim untuk melaksanakannya (ketentuan hukum waris yang telah diatur secara pasti tersebut). ${ }^{22}$ Senada dengan itu Muhammad 'Ali al-Ŝabûnî mengungkapkan bahwa makna pada kalimat ذَصِيبًا مَفْرُوضرًا “bagian yang telah ditentukan

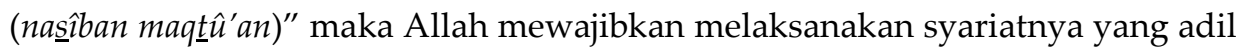
dan firmannya yang jelas (kitâbihi al-mubîn). ${ }^{23}$

Penjelasan tersebut menjadi dasar bahwa bagian waris dengan pembagian 2:1 antara anak laki-laki dan perempuan merupakan ketentuan yang qat́i serta jelas porsi pembagiannya sebagaimana telah ditetapkan oleh Allah. Dengan demikian tidak ada ruang bagi manusia untuk mengubah formulasi yang telah jelas tersebut sehingga dapat bertentangan dengan kehendak dan ketetapan Allah.

Untuk menjawab faktor-faktor yang menyebabkan syariat Islam membedakan bagian warisan antara laki-laki dan perempuan tersebut, Muhammad 'Alî al-Sâbûnî menjelaskan secara konseptual sebagai berikut: ${ }^{24}$

Pertama, nafkah perempuan telah ada yang menanggung. Nafkah tersebut menjadi tanggung jawab anak laki-laki, ayah, saudara laki-laki, dan keluarga laki-laki lainnya yang memiliki tanggung jawab memberikan nafkah.

${ }^{21}$ Abî Ja'far Muhammad bin Jarîr al-Tabarî, Jami' al-Bayân 'an Ta'wîl Ayy alQurân, Juz ke 6 (Bairût: Mustafâ al-Bâbi al-Halabi, 1968), h. 274-275.

${ }^{22}$ Abî al-Qâsim Jâr Allâh Mahmûd bin 'Umar al-Khawârizmî, Tafsîr al-Kasyâf: 'An Haqâa'iq al-Tanzîl Wa 'Uyûn al-Aqâwî̀l Fî̀ Wujûh al-Ta'wîl (Bairût: Dâr al-Ma'rifah, 2009), Jilid I, h. 221.

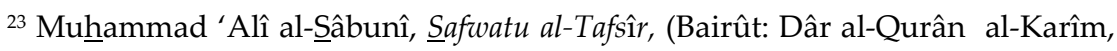
1981), Jilid I, h. 260.

${ }^{24}$ Muhammad 'Alî al-Ŝâûnî, ed, Al-Mawarits fi al-Syarî'ah al-Islamyyah 'ala Dau' al-Kitâb wa al-Sunnah, Penerjemah M. Samhuji Yahya, Hukum Waris dalam Syariat Islam, (Bandung: Diponogoro, 1987 M), Cet. 2, h. 23. 
Kedua, perempuan tidak dituntut untuk memberikan nafkah kepada siapapun. Sedangkan laki-laki memiliki tanggung jawab untuk menafkahi keluarga dan orang lain yang menjadi tanggung jawabnya.

Ketiga, kewajiban laki-laki untuk menafkahi memiliki macam yang beragam. Salah satu yang paling vital adalah berkaitan dengan materi. Sehingga kebutuhan laki-laki terhadap harta lebih besar dari pada perempuan.

Keempat, laki-laki dituntut memberikan mahar kepada Isteri. Selain itu memiliki kewajiban untuk memenuhi kebutuhan sandang, pangan dan papan isteri dan anak-anak.

Kelima, biaya pendidikan, biaya kesehatan anak dan isteri juga menjadi tanggung jawab laki-laki (suami) bukan tanggung jawab isteri.

Dari penjelasan Muhammad 'Alî al-Ŝâûnî di atas mengindikasikan bahwa laki-laki memiliki tanggung jawab lebih besar, karena laki-laki berkewajiban untuk memenuhi kebutuhan Isteri, anak, dan keluarga lain yang menjadi tanggung jawabnya. Sehingga bagian waris yang lebih besar tersebut dapat meringankan tanggung jawab laki-laki untuk memenuhi kebutuhankebutuhan yang ada dalam keluarga. Oleh karena itu ayat waris menjadi hak prerogatif Allah untuk mengatur pembagian serta pihak-pihak yang berhak menerima waris tersebut secara jelas dan detail tanpa campur tangan manusia, karena ayat tersebut terdapat hikmah dalam pembagian waris yang memiliki implikasi terhadap kewajiban serta tanggung jawab antara laki-laki dan perempuan di dalam kehidupan berumah tangga.

Selain hukum Islam, dalam konteks hukum kewarisan Indonesia juga dipengaruhi oleh hukum barat dan hukum adat dan dalam pembentukannya hukum warisan Islam di Indonesia merupakan kolaborasi antara hukum Islam, hukum barat dan hukum adat kemudian dikodifikasikan ke dalam suatu peraturan perundang-undangan. Tujuannya agar segala kepentingan warga masyarakat Indonesia yang beragam bisa terakomodir. Selain itu dalam praktiknya, masyarakat Indonesia menggunakan hukum kewarisan Islam tidak lepas dari corak budaya kekerabatan yang dianut, seperti corak kekerabatan patrilineal, kekerabatan matrilinial dan kekerabatan bilateral. Hal ini sebagaimana yang disampaikan oleh Sonny Kusuma sebagai Dewan Kehormatan PERADI DKI Jakarta, bahwa dalam sistem hukum nasional, hukum waris adat dakui dan berlaku bagi masyarakat adat setempat, hukum waris Islam diakui dan berlaku bagi masyarakat Islam dan hukum perdata (hukum barat) diakui dan berlaku bagi masyarakat non-muslim dalam pembagian dan penyelesaian waris. Namun Sonny juga menyebutkan pada 
faktanya pembagian waris Islam di Indonesia tidak selalu dipraktikan, umumnya masyarakat menggunakan pembagian waris berdasarkan hukum adat yang diyakini setempat. Sedangkan hukum waris Islam baru diterapkan manakala terdapat sengketa antara para pihak berkaitan dengan porsi pembagian waris. ${ }^{25}$

Secara umum, hukum kewarisan Islam di Indonesia menganut sistem hukum waris Islam sebagaimana ajaran madzhab sunni (madzhab Syafi'î, madzhab Hanafî, madzhab Hanbalî dan madzhab Mâlikî). Kemudian dalam perkembangannya, hadirlah Kompilasi Hukum Islam (KHI) yang menghimpun rangkaian kitab-kitab fikih dari pemikiran-pemikiran Imam Madzhab tersebut, selain itu Kompilasi Hukum Islam juga menjadi sumber hukum materil yang digunakan oleh Peradilan Agama dalam menyelesaikan masalah-masalah perkawinan, kewarisan, wakaf, dan hukum Islam di bidang perdata lainnya. ${ }^{26}$ Pelaksanaan Kompilasi Hukum Islam (KHI) berlaku bagi seluruh rakyat Indonesia yang beragama Islam atau mengenai sengketa non-muslim yang berhubungan dengan hak perdata masyarakat muslim. Hal ini berdasarkan Intruksi Presiden (Inpres) No. 1 tahun 1991.

Respon Kompilasi Hukum Islam terhadap formulasi pembagian waris 1:1 sebagaimana konsep pemikiran tokoh kontemporer Muhammad Syahrûr dan Munawir Sadzali, menurut penulis secara normatif saling bertentangan dengan norma hukum yang terdapat dalam Kompilasi Hukum Islam (KHI) pasal 176 mengenai besar bagian waris yang menyebutkan bahwa "Anak perempuan bila hanya seorang ia mendapat separoh bagian, bila dua orang atau lebih mereka bersama-sama mendapat dua pertiga bagian, dan apabila anask perempuan bersama-sama dengan anak laki-laki, maka bagian anak laki-laki adalah dua berbanding satu dengan anak perempuan."

Bunyi pasal tersebut merupakan saduran dari Q.S al-Nisâ' ayat 11 yang secara tekstual memberlakuan sistem pembagian waris berdasarkan sistem pembagian warisan 2:1, hal ini bisa dilihat melalui redaksi yang digunakan Kompilasi Hukum Islam adalah "mendapat" artinya ahli waris telah ditentukan porsi pembagian harta warisnya oleh Kompilasi Hukum Islam dengan pembagian warisan sebagaimana madzhab sunni (madzhab Syafi'î, madzhab

25 Hukum Waris Islam di Indonesia, Negara Hukum, https://www.negarahukum.com/hukum/hukum-waris-islam-di-indonesia.html, diakses pada tanggal 14 Februari 2020 Pukul 17.20.

${ }^{26}$ Muchit A. Karim, et.al, ed, Problematika Hukum Kewarisan Islam Kontemporer di Indonesia, (Jakarta: Puslitbang Kehidupan Keagamaan Bidang Litbang dan Diklat Kementerian Agama RI, 2012), Cet. 1, h. 112. 
Hanafî, madzhab Hanbalî dan madzhab Mâlikî). Dengan demikian secara umum Kompilasi Hukum Islam tetap mempertahankan doktrin fikih klasik dan merujuk pada nas-nas al-Qurân yang cocok, misalnya mengenai bagian warisan antara anak laki-laki berbanding dengan dua anak perempuan.

Mengenai bagian-bagian yang ahli waris peroleh, Kompilasi Hukum Islam telah mengaturnya secara prosedural yang terstruktur dan terukur. Sebagaimana dalam pasal 183 Kompilasi Hukum Islam disebutkan bahwa "Para ahli waris dapat bersepakat melakukan perdamaian dalam pembagian harta warisan, setelah masing-masing menyadari bagiannya."

Bunyi pasal ini menunjukkan bahwa para ahli waris yang telah menyadari pembagian warisan jika tidak terdapat perselisihan antara ahli waris mengenai bagian-bagian waris yang diperoleh, maka para ahli waris dapat membuat atau mengajukan permohonan penetapan ahli waris serta bagian yang diperolehnya kepada pihak berwenang. Namun, jika terdapat perselisihan antara para ahli waris mengenai pembagian harta warisan, maka penyelesaiannya adalah melalui Pengadilan Agama dengan cara mengajukan gugatan waris.

Hal ini sebagaimana diatur dalam pasal 188 Kompilasi Hukum Islam yang berbunyi "Para ahli waris baik secara bersama-sama atau perseorangan dapat mengajukan permintaan kepada ahli waris yang lain untuk melakukan pembagian harta warisan. Bila ada diantara ahli waris yang tidak menyetujui permintaan itu, maka yang bersangkutan dapat mengajukan gugatan melalui Pengadilan Agama untuk dilakukan pembagian warisan."

Tahapan-tahapan inilah yang menurut penulis dapat memberikan rasa keadilan, kemanfaatan dan kepastian hukum bagi masyarakat. Konsekuensi logis dari prosedural penyelesaian sengketa waris yang diatur dalam Kompilasi Hukum Islam, menurut penulis tidak mesti merubah formulasi hukum waris dengan metode kontemporer dengan alasan menyesuaikan kondisi dan perubahan zaman. Selama pemberlakuan hukum yang ada dapat memberikan rasa keadilan bagi masyarakat, maka ide pembaharuan tersebut tidak solutif. Sebagaimana yang dikatakan oleh Prof. Bustanul Arifin bahwa sebenarnya hadirnya Kompilasi Hukum Islam, bukan hanya sebagai bentuk reaktualisasi hukum Islam, namun juga merupakan sebuah reformasi hukum Islam. ${ }^{27}$

27 Busthanul Arifin, Pelembagaan Hukum Islam Di Indonesia: Akar Sejarah, Hambatan dan Prospeknya, (Jakarta: Gema Insani, 1982) h. 76. 
Walaupun aturan pembagian waris dalam hukum Islam sebagaimana diatur dalam nas al-Qurân dan penafsiran-penafsiran para ulama klasik serta sebagaimana yang tertuang dalam Kompilasi Hukum Islam sebagai sumber hukum materil masyarakat muslim Indonesia, namun ide pembaharuan yang melihat konteks sosial perkembangan zaman sebagaimana pemikiran Muhammad Syahrûr dan Munawir Sadzali merupakan langkah prefentif untuk menghindari terjadinya penyimpangan atau dualisme hukum yang dilakukan oleh masyarakat. Sungguhpun pengaturan yang terdapat dalam hukum Islam telah sangat terperinci dan jelas mengatur pembagian waris serta pihak-pihak yang berhak menerimanya, namun corak kehidupan masyarakat dan adatistiadat di suatu negara dapat mempengaruhi terjadinya perubahan-perubahan hukum. Sebagaimana M. Idris Ramulyo menjelaskan, bahwa perubahan hukum waris dalam suatu negara terjadi disebabkan karena: Pertama, pembagian waris sangat terperinci diatur dalam nas al-Qurân, namun ketika dalam praktiknya terdapat masalah, di dalam al-Qurân tidak dijelaskan bagaimana penyelesaiannya. Sehingga ijtihad terhadap hukum waris menjadi terbuka; Kedua, hukum waris merupakan hukum sosial bukan hukum eksakta. Oleh karena itu, terjadi perbedaan-perbedaan pendapat antara ahli hukum yang melahirkan banyak perspektif ${ }^{28}$ karena memang pengaturan hukum waris ini bersangkutan langsung dengan kehidupan sosial masyarakat.

Usaha untuk melakukan pembaharuan dalam sistem hukum waris menurut penulis merupakan langkah yang sangat penting untuk mengakomodir tuntutan zaman dan kepentingan masyarakat atau pihak-pihak tertentu yang selama ini merasa termarginalkan oleh hukum agama. Padahal kesalahan itu bukan disebabkan pengaturan hukum Islam, namun disebabkan oleh penafsiran-penafsiran yang cenderung kaku dan stagnan. Oleh karena itu bentuk dari kebijaksanaan pengaturan hukum Islam adalah memberikan kesempatan seluas-luasnya kepada para ulama, hakim, dan pemerintah untuk melakukan ijttihâd, menganalisa dan memecahkan permasalahan yang dihadapi oleh individu dan kelompok masyarakat dalam suatu negara. Selanjutnya setelah menganalisa secara tekstual, para ahli mengkaji persoalan hukum tersebut berdasarkan kontekstual guna menetapkan ketetapan hukum dari hasil ijtihadnya tersebut.

Dengan demikian hukum Islam dapat memberikan kemaslahatan dan kemajuan hukum dalam masyarakat serta hukum Islam dapat diterima dengan baik oleh masyarakat karena fleksibelitas yang dimilikinya dapat menjawab

${ }^{28}$ M. Idris Ramulyo, Perbandingan Pelaksanaan Hukum Kewarisan Menurut KUH Perdata Dan Islam, (Jakarta: Sinar Grafika, 1994), h. 6. 
persoalan-persoalan yang dihadapi masyarakat sesuai dengan kondisi tempat, zaman, ruang dan waktu.

Dalam konteks keindonesiaan, corak kekerabatan seperti patrilineal akan berbeda penerapan hukum warisnya dengan kekerabatan matrilineal dan begitu sebaliknya. Dalam al-Qurân tentang ayat-ayat kewarisan Islam, tidak dijelaskan mekanisme penyelesaian persoalan budaya tersebut dalam pembagian waris. Sedangkan awal mula turun ayat yang mengatur hukum kewarisan Islam bercorak kekerabatan patrilinial sebagaimana yang dianut oleh masyarakat Arab pada umumnya. Sehingga para ahli hukum Islam yang berada di luar wilayah Arab akan mengembangkan ayat waris dan ketetapan hukum berdasarkan sistem kekerabatan yang dianut dalam kehidupan masyarakatnya tersebut.

Ide pembaharuan mengenai hukum waris salah satu tokoh yang berkontribusi adalah Muhammad Syahrûr. Syahrûr disebut-sebut merupakan tokoh yang memiliki konsep pembaharuan berkaitan dengan fikih secara inovatif. Ide pembaharuan tersebut dituangkan ke dalam sebuah teori yang dikenal dengan teori Limit, di dalamnya mengatur rumusan waris secara matematis yang disesuaikan dengan kondisi atau peran perempuan di dalam kehidupan keluarga. Selain itu teori limit merupakan gagasan orsinil Muhammad Syahrûr yang memiliki dedikasi besar dalam pembaharuan hukum waris Islam. Sebagaimana menurut Hallaq bahwa pemikiran Muhammad Syahrûr bukan hanya menemukan metodologi yang sesuai dengan pemikiran Islam, namun pemikirannya dapat mengelaborasi antara konsep tekstual dan kontekstual sehingga metode yang dihasilkan oleh Muhammad Syahrûr lebih humanis. ${ }^{29}$ Senada dengan itu, Andreas Christman dalam sebuah pengantar yang dipersembahkan untuk karya buku Muhammad Syahrûr yang berjudul "Nahwu Us sul Jadîdah Lil Fighi al-Islâmi" menyatakan bahwa pendekatan yang dilakukan oleh Muhammad Syahrûr sebagai sebuah metode yang tidak biasa karena dianggap pendekatannya tidak umum dan mencitrakan kehendak nyata untuk meruntuhkan norma penafsiran yang sudah baku serta melawan "pembiasaan" cara baca konvensional dengan menawarkan jalan "alternatif" untuk membaca sebuah teks. ${ }^{30}$ Metode pembacaan teks dan pengkajian makna asli dalam sebuah teks al-Qurân yang dilakukan oleh Muhammad Syahrûr tidak biasa dilakukan oleh para ulama

29 Afif Muamar, "Rekonstruksi Hukum Islam (Telah Pemikiran Muhammad Syahrur)", h. 209.

${ }^{30}$ Muhammad Shahrur, Nahwwu Usîul Jadîdah Lilfighi al-Islâmî, Editor Sahiron Syamsuddin, Metodologi Figh Islam Kontemporer, h. 17-18.

Journal of Legal Research. Volume 3, Nomor 4 (2021). ISSN: 2715-7172. E-ISSN: 2715-7164 - 529 
pada umumnya. Sebagaimana Amin Abdullah menyatakan bahwa Muhammad Syahrûr dalam melakukan pembaharuan penafsiran hukum waris Islam yakni menggunakan pendekatan hermeneutika dengan penekanan pada aspek filologi (figh lughah). ${ }^{31} \mathrm{Hal}$ ini menunjukkan bahwa metode pembaharuan hukum kewarisan Islam yang ditawarkan oleh Muhammad Syahrûr berangkat dari kebenaran terhadap pembacaan teks al-Qurân. Dengan metode pembacaan yang benar terhadap teks al-Qurân akan membawa kepada pemahaman pembacaan secara kontekstual.

Selain Muhammad Syahrûr, berkaitan dengan ide pembaharuan, Munawir Sadzali merupakan salah satu kontributor yang menawarkan satu konsep pembaharuan hukum di bidang kewarisan Islam melalui teorinya yang dikenal dengan Reaktualisasi Ajaran Islam. Pemikiran Munawir Sadzali ini membuktikan bahwa ide pembaharuan itu bukan hanya terkonstruksi pada wilayah Arab saja, namun ide pembaharuan itu dapat hadir dan berangkat dari problematika masyarakat Indonesia. Seperti yang ditegaskan K.H Sahal Mahfudz, bahwa kitab itu harus diterjemahkan secara metodologis dan proporsional, sehingga hukum Islam tidak kehilangan elemen vitalnya. Sahal juga mengatakan bahwa fiqh itu terbentuk dari pergulatan antara teks dan konteks, dan dalam fikih metode kontekstual itu yang harus senantiasa dikembangkan karena fikih mengandung makna penalaran atas persoalanpersoalan hukum. Terma tersebut disadur oleh Sahal dari ungkapan Imam Ghazali yang menyatakan bahwa para ulama itu harus mampu menangkap pesan zaman demi kemaslahatan umat. ${ }^{32}$

Setiap perubahan memiliki karakter yang berbeda dalam memberikan semangat berkelanjutan secara berkesinambungan untuk menjawab problematika-problematika yang dihadapi masyarakat muslim. Munawir Sadzali menempatkan dirinya sebagai Menteri Agama yang memiliki tanggung jawab besar mengenai dinamika hukum Islam yang dihadapi oleh masyarakat Indonesia. Untuk itu, ia mencoba memanfaatkan sebaik-baiknya posisi sebagai Menteri Agama juga sebagai seorang yang telah cukup pengetahuannya di bidang agama dan hukum Islam agar dapat memecahkan persoalan yang dihadapi masyarakat tersebut. Seperti yang dikatakan oleh Farouq Abu Zaid bahwa fikih merupakan refleksi logis dari situasi dan kondisi dimana fikih itu berkembang.

31 Amin Abdullah, Neo Ushul Fiqih Menuju Ijtihad Kontekstual, (Yogyakarta: Fakultas Syari'ah Press dan Forum Studi Hukum Islam, 2004), h. 150.

32 Sahal Mahfudz, Nuansa Figh Sosial, (Yogyakarta: LKiS, 1994), h. 71. 
Penolakan terhadap nas oleh Munawir Sadzali menurut penulis merupakan suatu konsep pemikiran yang memiliki kolerasi dengan prinsip bahwa hukum itu berubah bersama dengan perubahan zaman, tempat, dan keadaan. Kaidah ini menurut penulis bukan berarti mengabaikan kandungan yang ada di dalam nas, juga bukan berarti menutup kesempatan para ulama melakukan ijtihâd. Namun lebih mengedepankan kemaslahatan demi menyelesaikan persoalan yang dihadapi oleh masyarakat kepada suatu metode tepat, tanpa meninggalkan ensensi dari hukum Islam. Hukum adat yang menjadi titik tolak atau permulaan munculnya pemikiran Munawir Sadzali adalah menjadi suatu tolak ukur yang tepat, karena dengan begitu hukum Islam akan dapat mengantisipasi perubahan hukum dalam masyarakat yang terus berkembang, tanpa menghilangkan esensi dari prinsip Islam yakni keadilan, persamaan, kebebasan dan persaudaraan. Tidak bisa dipungkiri bahwa hukum adat telah mengakar dengan kuat dalam sendi masyarakat Indonesia, sehingga Hukum Islam harus mampu bersifat fleksibel agar dapat difahami dan diterima oleh masyarakat serta dapat diaplikasikan dalam kehidupan masyarakat. Sebagaimana menurut Fahmi Muhammad Ahmadi, bahwa hukum Islam merupakan hukum yang mempunyai fleksibelitas tinggi. Tujuannya agar tidak menyempitkan manusia dalam melaksanakan hukum. Dengan demikian jika perbedaan-perbedaan tidak mampu disikapi oleh hukum Islam dengan adaptabilitas hukumnya, maka hukum Islam akan sulit menjadi suatu tatanan sosial masyarakat. Hal inilah yang kemudian Fahmi Muhammad Ahmadi menjelaskan bahwa adanya adaptabilitas dalam hukum Islam justru membawa keuntungan jika berhadapan dengan pluralitas masyarakat, karena parameternya merupakan kemaslahatan dan keadilan sosial yang objektif. ${ }^{33}$ Senada dengan itu menurut Euis Nurlaelawati negara harus mampu merespon dan melakukan pembaharuan hukum Islam untuk mengakomodir kepentingan tuntutan zaman dan mempertahankan keberlangsungan pemberlakuan hukum keluarga Islam. ${ }^{34}$

Penulis menganggap bahwa ketentuan fikih harus sesuai dengan kebutuhan masyarakat yakni harus terbentuk dari kondisi, lingkungan dan tradisi setempat hukum tersebut diberlakukan, sehingga implementasi hukum Islam dapat berjalan dengan baik karena adanya dorongan kesadaran masyarakat untuk menerapkan hukum Islam, khususnya hukum waris. Bukan

33 Fahmi Muhammad Ahmadi, “Adaptabilitas Hukum Islam di Indonesia dalam Berbagai Model", Jurnal Refleksi, X, 2, (2008), h. 135.

34 Euis Nurlaelawati, "Menuju Kesetaraan dalam Aturan Kewarisan Islam Indonesia: Kedudukan Anak Perempuan Versus Saudara Kandung", Jurnal Indo-Islamika, 2, 1, (2012), h. 76. 
hanya terpacu pada konsep yang telah ada, padahal konsep tersebut memiliki perbedaan ruang waktu, kondisi dan zaman. Untuk itu perlu suatu konsep pembaharuan dalam sistem hukum Islam. Sebagaimana menurut Ibnu Taimiyah bahwa sesuatu yang dikemas oleh mujathid bukanlah sesuatu hal final dan telah tepat dalam menyikapi berbagai dinamika umat manusia. Ibnu Taimiyah mengharuskan membuang sifat kejumudan dan fanatisme madzhab, serta mengharuskan umat Islam menyuarakan semangat ijtihad dan membuka pintu ijtihad seluas-luasnya. ${ }^{35}$

Semangat dalam melakukan ijtihad tersebut tercermin dalam konsepkonsep pembaharuan sebagaimana pemikiran Muhammad Syahrûr dan Munawir Sadzali. Konsep keduanya merupakan suatu konsep yang mampu mendobrak suatu kekakuan dalam agama, karena problem hukum Islam saat ini adalah kesulitan dalam merespon tuntutan realitas zaman modern. Jika hukum Islam tidak mampu dalam merespon problematika kontemporer tersebut, tentu implikasinya adalah hukum Islam mulai ditinggalkan dalam konteks pelaksanaannya oleh umat Islam itu sendiri. Sebenarnya konsep yang diinisiasi oleh Muhammad Syahrûr mengenai teori batas, dapat bermanfaat bagi perkembangan hukum Islam dalam menjawab tuntutan zaman di masa yang akan datang. Konsep tersebut memiliki batas minimal dan batas maksimal dalam setiap konsep fikih. Dalam batasan ini para ulama memiliki kebebasan untuk menafsirkan problematika yang dihadapi masyarakat sesuai kebutuhan zaman dengan porsi tidak kurang dari batas minimal dan tidak melebihi batas maksimal, berdasarkan ketentuan yang telah ditetapkan. Begitupun konsep yang ditawarkan oleh Munawir Sadzali melalui teori reaktualisasi ajaran Islam. Munawir melihat bahwa perkembangan dari problematika hukum yang dihadapi oleh masyarakat merupakan sunnatullah yang harus bisa dicarikan solusinya oleh para ulama, penegak hukum dan pemerintah. Sudut pandang mengenai ketetapan hukum yang ada harus berangkat dari bagaimana tujuan hukum itu terbentuk. Misalkan hukum waris, yakni tujuan terbentuknya adalah untuk mengangkat derajat perempuan dan memberikan pesan kesetaraan dalam Islam. Tujuan tersebut yang harus difokuskan dalam memahami ayat al-Qurân. Dengan demikian konsep dari Muhammad Syahrûr dan Munawir Sadzali merupakan konsep yang memang berangkat dari situasi dan kondisi hukum diberlakukan serta melihat peran perempuan dalam perkembangan modernitas yang memposisikan perempuan dan laki-laki seimbang, karena secara historis turunnya ayat kewarisan ini adalah untuk

35 Sucipto, "Pembaharuan Hukum Islam (Study Terhadap Pemikiran Hukum Ibnu Taimiyah)", Jurnal Asas, 3, 1, (Januari, 2011), h. 51. 
memberikan rasa keadilan antara umat Islam dan untuk meningkatkan kesejahteraan. Dengan demikian dapat dikatakan bahwa formulasi pembagian waris 2:1 merupakan sebuah metode untuk mencapai tujuan itu (keadilan dan kesejahteraan). Oleh karena itu metode dapat saja berubah mengikuti tujuan, namun tujuan tetap harus dipertahankan dan tidak bisa dirubah.

\section{KESIMPULAN}

Konsep pembaharuan dalam sistematika pembagian waris Islam secara proporsional dapat dilakukan sebagaimana yang ditawarkan oleh pemikiran Muhammad Syahrûr yakni dengan suatu teori yang dikenal dengan Teori Batas (Teori Limit) sebagaimana yang disampaikan oleh Muhammad Syahrûr bahwa makna yang terkandung di dalam Q.S al-Nisâ' ayat 11 mengatur ketentuan batas minimal bagian anak perempuan adalah $33,33 \%$ atau satu bagian, sedangkan batas maksimal yang dimiliki oleh anak laki-laki adalah $66,66 \%$ atau dua bagian kelompok perempuan. Batasan-batasan tersebut dapat diterapkan dalam sistematika pembagian waris, dengan catatan tidak melebihi batas maksimal dan tidak kurang dari batas minimal sebagaimana yang telah ditentukan Allah dalam surat al-Nisâ' tersebut. Selain itu Muhammad Syahrûr memberikan catatan bahwasannya keterlibatan perempuan dalam menafkahi keluarga mempengaruhi porsi bagian waris yang didapatkan. Dengan demikian, jika perempuan tidak sama sekali terlibat dalam menafkahi keluarga, porsinya sebagaimana semestinya sesuai dengan ketentuan 2:1. Sedangkan dalam konteks keindonesiaan salah satu tokoh yang menawarkan konsep pembaharuan pembagian waris secara proporsional adalah Munawir Sadzali dengan teori yang dibawanya dikenal sebagai teori Reaktualisasi Ajaran Islam. Munawir dalam hal pembagian waris ini mengajak masyarakat Indonesia untuk memperhatikan konteks peran wanita dalam kondisi masyarakat pada saat teks al-Qurân diturunkan dengan peran wanita dalam kondisi masyarakat modern yang meletakkan peran perempuan sama dengan laki-laki, sebagai individu yang dibebani tanggung jawab menafkahi keluarga. Untuk itu diperlukan adanya rumusan baru yang tepat dan sesuai dengan zaman, waktu, kondisi serta semangat keadilan yang dibawa Islam ketika membawa ketentuan waris dengan memberikan hak waris kepada wanita yang pada saat itu sama sekali tidak memiliki hak mendapatkan bagian waris. Sehingga dengan meningkatkan hak waris perempuan sama dengan laki-laki merupakan solusi dari menyikapi ketentuan waris 2:1 yang selama ini menimbulkan problematika sosial dalam masyarakat Indonesia. 
Pada putusan Pengadilan Agama Medan No.92/Pdt.G/2009/PA.Mdn berdasarkan hasil analisis penulis terdapat amar putusan yang belum jelas, misalnya mengenai kedudukan ayat waris, majelis hakim belum mengidentifikasi kategori tersebut. Apakah kedudukan ayat waris tersebut bagian dari ayat zanny atau masuk kategori ayat yang qat $i$. Kategori ayat tersebut perlu diuraikan terlebih dahulu sebelum hakim menyatakan dalam penjelasan pertimbangannya bahwa "Kompilasi Hukum Islam bukanlah sebuah harga mati yang sama sekai tidak dapat dirubah lagi, terutama ketika permasalahannya terkait dengan rasa keadilan itu sendiri merupakan salah satu 'illat hukum (penyebab yang dapat mengakibatkan terjadinya perubahan hukum)". Dengan begitu pertimbangan majelis hakim akan memiiki pijakan hukum yang kuat dan jelas. Namun hadirnya putusan Pengadilan Agama Medan No.92/Pdt.G/2009/PA.Mdn menjadi contoh bahwa Indonesia pernah menerapkan sistem pembagian waris secara proporsional antara laki-laki dan perempuan. Sehingga penerapan pembagian sistem pembagian waris secara proporsional yakni 1:1 antara laki-laki dan perempuan telah memiliki legitimasi berdasarkan putusan hakim sebagai bentuk yurisprudensi.

\section{REFERENSI:}

\section{$\underline{\text { BUKU }}$}

Abdullah, Amin. Neo Ushul Fiqih Menuju Ijtihad Kontekstual. Yogyakarta: Fakultas Syari'ah Press dan Forum Studi Hukum Islam, 2004

Al-Khawârizmî, Abî al-Qâsim Jâr Allâh Mahmûd bin 'Umar. Tafsîr al-Kasyâf: 'An Haqâ'iq al-Tanzîl Wa 'Uyûn al-Aqâwwîl Fî Wujûh al-Ta'wîl. Jilid I. Bairût: Dâr al-Ma'rifah, 2009

Al-Ŝâûnî, Muhammad 'Alî. ed, Al-Mawarits fi al-Syarî'ah al-Islamyyah 'ala Dau' al-Kitâb wa al-Sunnah. Penerjemah M. Samhuji Yahya. Hukum Waris dalam Syariat Islam. Cet. 2. Bandung: Diponogoro, 1987

Al-Ŝâuûnî, Muhammad 'Alî. Safwatu al-Tafsîr. Jilid I. Bairût: Dâr al-Qurân alKarîm, 1981

Al-Tabari, Abî Ja'far Muhammad bin Jarîr. Jami' al-Bayân 'an Ta'wîl Ayy al-

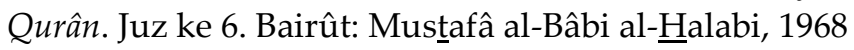

Arifin, Busthanul. Pelembagaan Hukum Islam Di Indonesia: Akar Sejarah, Hambatan dan Prospeknya. Jakarta: Gema Insani, 1982

Hasan, Hasniah. Hukum Warisan Dalam Islam. Surabaya: Bina Ilmu, 1994 
Karim, Muchit A. et.al, ed, Problematika Hukum Kewarisan Islam Kontemporer di Indonesia. Cet. 1. Jakarta: Puslitbang Kehidupan Keagamaan Bidang Litbang dan Diklat Kementerian Agama RI, 2012

Lukito, Ratno. Hukum Sakral dan Hukum Sekuler: Studi Tentang Konflik dan Resolusi dalam Sistem Hukum Indonesia. Tangerang: Pustaka Alvebet, 2008

Mahfudz, Sahal. Nuansa Figh Sosial. Yogyakarta: LKiS, 1994

Muhibbin, Moh dan Abdul Wahid. Hukum Kewarisan Islam: Sebagai Pembaharu Hukum Positif di Indonesia. Jakarta: Sinar Grafika Bumi Aksara, 2011

Mudzhar, Atho. dan Khairuddin Nasution, ed.al, eds., Hukum Keluarga di Dunia Islam Modern. Jakarta Selatan: Ciputat Press, 2003

Mursyid, Hasbullah. "Menelusuri Faktor Sosial yang Mungkin Berpengaruh" dalam Muh. Wahyuni Nafis. Kontekstualisasi Ajaran Islam (70 th Prof Munawir Syadzali). Jakarta: Paramadina dan IPHI, 1995

Ramulyo, M. Idris. Perbandingan Pelaksanaan Hukum Kewarisan Menurut KUH Perdata dan Islam. Jakarta: Sinar Grafika, 1994

Rawls, John. ed, ATheory of Justice. Penerjemah Uzair Fuzan dan Heru Prasetyo, Teori Keadilan: Dasar-dasar Filsafat Politik untuk Mewujudkan Kesejahteraan Sosial dalam Negara. Cet. 2. Yogyakarta: Pustaka Pelajar, 2011

Shahrur, Muhammad. ed, Nahwu Us ŝul Jadîdah Lilfighi al-Islâmî. Editor Sahiron Syamsuddin. Metodologi Fiqh Islam Kontemporer. Yogyakarta: el.SAQ Press, 2004

Suma, Muhammad Amin. Keadian Hukum Waris Islam: Dalam Pendekatan Teks dan Konteks. Cet. 1. Jakarta: PT. Grafindo Persada, 2013

Suparman, Eman. Hukum Waris Indonesia: Dalam Perspektif Islam, Adat, dan BW . Bandung: Refiks Aditama, 2005

Syaukani, Imam. Rekonstruksi Epistimologi Hukum Islam Indonesia. Jakarta: Raja Grafindo Persada, 2006

Yahya, Mukhtar dan Fatchurrahman. Dasar-dasar Pembinaan Hukum Figh Islam Cet. 3. Bandung: Al-Ma'arif, 1993

Yanggo, Huzaemah T. Hukum Keluarga Dalam Islam. Jakarta: Yayasan Masyarakat Indonesia Baru, 2013. 


\section{JURNAL}

Ahmadi, Fahmi Muhammad. "Adaptabilitas Hukum Islam di Indonesia dalam Berbagai Model”. Jurnal Refleksi. Vol. X, No.2, (2008)

Aziz, Abdul. "Pembagian Waris Berdasarkan Tingkat Kesejahteraan Ekonomi Ahli Waris dalam Tinjauan Maqashid Shariah". De Jure: Jurnal Hukum dan Syari'ah. Vol. 8, No. 1, (Juni, 2016)

Malarangan, Hilal. "Pembaharuan Hukum Islam Dalam Hukum Keluarga di Indonesia". Jurnal Hunafa. Vol. 5 No. 1, (April, 2008)

Muamar, Afif. "Rekonstruksi Hukum Islam (Telah Pemikiran Muhammad Syahrur)". Jurnal Mahkamah Kajian Hukum Islam. Vol. 2, No. 2, (Desember 2017)

Muhammad, Razimah Wan. "Woman and Shari'ah Court: A Study of Malaysia and Indonesia. International Journal of Cross-Cultural Studies". Vol. 1, No. 2, (Desember, 2015)

Mustafid, Fuad. "Pembaharuan Pemikiran Hukum Islam: Studi Tentang Teori Hudud Muhammad Syahrur". Jurnal Al-Madzahib. Vol. 5, No. 2, (Desember, 2017)

Nurlaelawati, Euis. "Menuju Kesetaraan dalam Aturan Kewarisan Islam Indonesia: Kedudukan Anak Perempuan Versus Saudara Kandung". Jurnal Indo-Islamika. Volume 2, Nomor 1, (2012)

Permana, Sugiri. "Kesetaraan Gender dalam Ijtihad Hukum Waris Islam di Indonesia". Jurnal Asy-Syari'ah. Vol. 20, No. 2, (Desember, 2012)

Sucipto. "Pembaharuan Hukum Islam (Study Terhadap Pemikiran Hukum Ibnu Taimiyah)". Jurnal Asas. Vol. 3, No. 1, (Januari, 2011)

\section{$\underline{\text { SKRIPSI }}$}

Panjaitan, Sunardi. Skripsi Teori Batas Hukum Islam: Studi Terhadap Pemikiran Muhammad Syahrur Dalam Waris. Skripsi S-1 Fakultas Syariah dan Hukum, Universitas Islam Negeri Syarif Hidayatullah Jakarta, 2008

\section{INTERNET}

Hukum Waris Islam di Indonesia. Negara Hukum. https:/www.negarahukum.com/hukum/hukum-waris-islam-di-indonesia.html 